\title{
ANALISIS NILAI PRAKTIKUM EDUKATOR PELAYANAN DARAH TERHADAP NILAI UJIAN AKHIR SEMESTER (UAS) KOMUNIKASI INFORMASI EDUKASI (KIE) DAN PROMOSI KESEHATAN
}

\author{
${ }^{1}$ Danik Riawati* \\ ${ }^{1}$ Akademi Teknologi Bank Darah Surakarta \\ ${ }^{1}$ riawatidanik81@gmail.com*
}

\begin{abstract}
Abstrak
Latar Belakang : Lulusan mahasiswa Diploma III Teknologi Bank Darah diharapkan mampu bertindak sebagai teknisi pelayanan darah, pelaksana pengujian mutu produk darah dan edukator layanan darah. Salah satu contoh yaitu mampu bertindak sebagai edukator layanan darah, artinya mahasiswa harus mampu menjadi teknisi dalam memberikan komunikasi, informasi, edukasi di pelayanan darah.
\end{abstract}

Tujuan : untuk mengetahui hubungan antara nilai praktikum sebagai edukator layanan darah terhadap nilai Ujian Akhir Semester (UAS) Komunikasi Informasi Edukasi (KIE) dan Promosi Kesehatan.

Metode : Penelitian ini menggunakan metode observasional analitik dengan pendekatan cross sectional. Populasi penelitian ini adalah semua mahasiswa tingkat II Akademi Teknologi Bank Darah Surakarta. Subyek penelitian ini semua mahasiswa tingkat II Akademi Teknologi Bank Darah Surakarta sebanyak 64 orang. Teknik pengambilan sampel menggunakan sampling jenuh. Alat pengumpulan data berupa formulir penilaian. Analisa data menggunakan uji koefisien korelasi Spearman's rho.

Hasil : Nilai output didapatkan koefisien korelasi Spearman's rho sebesar 0,693, sehingga hubungan antara nilai praktikum edukator pelayanan darah dengan nilai UAS KIE dan Promosi Kesehatan adalah kuat. Nilai koefisien bertanda positif arti terjadi hubungan posistif, yaitu jika nilai praktikum edukator pelayanan darah tinggi maka nilai UAS KIE dan Promosi Kesehatan juga tinggi atau sebaliknya.

Simpulan : Nilai signifikansi sebesar $0,000<0,05$ maka hipotesis nol di tolak, artinya ada hubungan yang berarti antara nilai praktikum edukator pelayanan darah dengan nilai UAS KIE dan Promosi Kesehatan.

Kata kunci : Nilai Praktikum Edukator Pelayanan Darah; Nilai UAS; KIE dan Promosi Kesehatan

\section{PRACTICAL VALUES ANALYSIS OF BLOOD SERVICE FOR FINAL EXAM VALUE SEMESTER (UAS) EDUCATION INFORMATION COMMUNICATION (KIE) AND HEALTH PROMOTION}

\begin{abstract}
Background: Graduate Diploma III technology Blood Bank is expected to be able to act as a blood service technician, implementers the quality of blood products and care for blood service educators. One example is able to act as blood service
\end{abstract}


educators, meaning that students must be able to become technicians in providing communication, information, education in blood services.

Objective: To find out the relationship between the practicum value as a blood service educator to the value of the final Semester exam (UAS) Education Information Communication (KIE) and health promotion.

Methods: This research uses analytical methods of observational with cross sectional approaches. The population of this research is all level II students of the Blood Bank's technology Academy Surakarta. The subject of this study was all level II students of the Technology Academy of Surakarta Blood Bank as much as 64 people. Sampling techniques use saturated sampling. The Data collection tool is a valuation form. Analysis of data using correlation coefficient of Spearman's rho.

Result: The value of output obtained the correlation coefficient of Spearman's rho of 0.693, so the relationship between practicum value of blood service with the value of UAS KIE and health promotion is strong. Coefficient value marked positive meaning of posistive relationships, i.e. if the value of practicum of high blood service Edup then the value of UAS KIE and health promotion is also high or vice versa.

Conclusion: The significance value is $0.000<0.05$, then the zero hypothesis is rejected, meaning there is a meaningful relationship between the value of the practicum of blood service with the value of UAS KIE and health promotion.

Key words: The value of practicum of blood service edurating; UAS; KIE and Health Promotion

\section{PENDAHULUAN}

Salah satu program prioritas pemerintah di bidang kesehatan adalah memperjuangkan penurunan Angka Keatian Ibu (AKI) yang saat ini masih tergolong tinggi. Kematian ibu di Indonesia di dominasi oleh tiga penyebab utama yaitu perdarahan, hipertensi dalam kehamilan dan infeksi. Salah satu upaya untuk menurunkan AKI melahirkan adalah melalui pemenuhan kebutuhan darah bagi ibu melahirkan dengan komplikasi perdarahan, sehingga membutuhkan pelayanan darah yang aman dan berkualitas, serta perlu didukung dengan ketersediaan darah sesuai kebutuhan (Infodatin, 2017). Hal tersebut juga didukung oleh Undangundang No, 36 Tahun 2014 tentang tenaga kesehatan mengatur pendidikan vokasi paling rendah adalah Diploma III. Contoh pendidikan Diploma III Teknologi Bank Darah. Pendidikan ini di tuntut profesionalisme melalui peningkatan pengetahuan, ketrampilan dan sikap tenaga kesehatan di bidang pelayanan darah. Hai ini dikarenakan pelayanan darah merupakan bagian yang tidak terpisahkan dari pelayanan kesehatan kepada masyarakat. Adapun profil lulusan Diploma III Teknologi Bank Darah yaitu mahasiswa mampu bertindak sebagai teknisi pelayanan darah, pelaksana pengujian mutu produk darah dan edukator layanan darah (Kemenkes RI, 2018). Berdasarkan hal tersebut maka perkembangan ilmu pengetahuan dan teknologi di bidang kedokteran khususnya teknologi pelayanan darah, pengelolaan komponen darah dan pemanfaatannya dalam pelayanan kesehatan harus memiliki landasan hukum konsekuensi asas negara berlandaskan 
hukum., oleh karena itu pelayanan darrah hanya dilakukan oleh Sumber Daya Masyarakat (SDM) yang memiliki kompetensi dan kewenangan dan hanya dilaksanakan pada farsilitas pelayanan kesehatan yang memenuhi persyaratan (Menkes RI, 2015). Salah satu contohnya yaitu sebagai edukator layanan darah. Kompetensi ini perlu diterapkan sejak menjadi mahasiswa DIII Teknologi Bank Darah, artinya mahasiswa harus mampu menjadi teknisi dalam memberikan komunikasi, informasi, edukasi di pelayanan darah. Kompetensi berupa mampu memberikan komunikasi, informasi, edukasi di pelayanan darah yang dimasukkan dalam mata kuliah KIE dan Promosi Kesehatan. Hal ini dikarenakan komunikasi merupakan suatu proses pengoperasian rangsangan dalam bentuk lambang atau simbuol bahasa atau gerakan untuk mempengaruhi perilaku orang lain. Beberapa unsur komunikasi antara lain komunikator, komunikan, pesan dan saluran atau media (Notoatmojo S, 2012).

Berdasarkan urian diatas maka penulis tertarik mengambil judul penelitian “ Analisa Nilai Praktikum Edukator Layanan Darah Terhadap Nilai Ujian Akhir Semester (UAS) Komunikasi Informasi Edukasi (KIE) dan Promosi Kesehatan“. Penelitian ini mempunyai tujuan untuk mengetahui hubungan antara nilai praktikum sebagai edukator layanan darah terhadap nilai Ujian Akhir Semester (UAS) Komunikasi Informasi Edukasi (KIE) dan Promosi Kesehatan.

\section{METODE}

Penelitian ini menggunakan metode observasional analitik dengan pendekatan cross sectional. Populasi penelitian ini adalah semua mahasiswa tingkat II Akademi Teknologi Bank Darah Surakarta. Subyek penelitian ini semua mahasiswa tingkat II Akademi Teknologi Bank Darah Surakarta yang sebanyak 64 orang. Teknik pengambilan sampel menggunakan sampling jenuh. Metode pengumpulan data menggunakan data primer dan sekunder. Alat pengumpulan data berupa formulir penilaian pada semester gasal TA 2019/2020. Teknik pengolahan data menggunakan editing, coding, tabulating dan entering. Analisa data bivariat menggunakan uji koefisien korelasi Spearman's rho dengan bantuan program SPSS versi 26.

\section{HASIL DAN PEMBAHASAN}

Tabel 1. Distribusi Frekuensi Nilai Praktikum Edukator Layanan Darah Terhadap Nilai UAS KIE dan Promosi Kesehatan

\begin{tabular}{|c|c|c|c|c|c|}
\hline variabel & $\mathrm{n}$ & Minimum & Maximum & Mean & SD \\
\hline $\begin{array}{c}\text { Nilai Praktikum Edukator Layanan } \\
\text { Darah }\end{array}$ & 64 & 70 & 88 & 81,05 & 4,061 \\
\hline $\begin{array}{l}\text { Nilai UAS KIE dan Promosi } \\
\text { Kesehatan }\end{array}$ & 64 & 60 & 86 & 76,16 & 7,340 \\
\hline
\end{tabular}

Tabel 1 didapatkan bahwa jumlah responden sebanyak 64 dengan nilai minimum praktikum edukator layanan darah yaitu 70 dan nilai maximum UAS KIE dan Promosi Kesehatan yaitu 60, nilai maximun praktikum edukator layanan darah yaitu 88 dan nilai maximum UAS KIE dan Promosi Kesehatan adalah 86, nilai mean praktikum edukator layanan darah yaitu 81,05 dan nilai mean UAS KIE dan 
Promosi Kesehatan adalah 76,16, nilai standar deviasi (SD) praktikum edukator layanan darah yaitu 4,061 dan nilai standar deviasi (SD) UAS KIE dan Promosi Kesehatan adalah 7,340.

Tabel 2. Distribusi Frekuensi Nilai Praktikum Edukator Layanan Darah

\begin{tabular}{ccc}
\hline Kategori & Frekuensi & Prosentase (\%) \\
\hline$<70$ & 0 & 0 \\
$>70$ & 64 & 100 \\
Jumlah & 64 & 100 \\
\hline
\end{tabular}

Tabel 2 didapatkan bahwa seluruh responden mendapakan nilai praktikum edukator layanan darah yaitu nilai $>70$ yaitu sebanyak 64 responden $(100 \%)$.

Tabel 3. Distribusi Frekuensi Nilai UAS KIE dan Promosi Kesehatan

\begin{tabular}{ccc}
\hline Kategori & Frekuensi & Prosentase $(\%)$ \\
\hline$<70$ & 12 & 18,8 \\
$>70$ & 52 & 81,3 \\
Jumlah & 64 & 100 \\
\hline
\end{tabular}

Tabel 3 didapatkan bahwa mayoritas responden mendapatkan nilai UAS KIE dan Promosi Kesehatan yaitu nilai $>70$ yaitu sebanyak 52 responden $(81,3 \%)$ dan nilai $<70$ sebanyak 12 responden $(18,8 \%)$.

Tabel 4. Tabulasi Silang Analisa Nilai Praktikum Edukator Layanan Darah Terhadap UAS KIE dan Promosi Kesehatan

\begin{tabular}{|c|c|c|c|c|c|c|}
\hline \multirow{2}{*}{$\begin{array}{c}\text { Nilai Praktikum } \\
\text { Edukator Layanan } \\
\text { Darah }\end{array}$} & \multicolumn{4}{|c|}{$\begin{array}{c}\text { Nilai UAS KIE dan Promosi Kesehatan } \\
<\mathbf{7 0}\end{array}$} & \multirow{2}{*}{ Jumlah } & \multirow{2}{*}{ Prosentase $(\%)$} \\
\hline & Frekuensi & $\begin{array}{c}\text { Prosentase } \\
(\%)\end{array}$ & $\begin{array}{c}\text { Frekuen } \\
\text { si }\end{array}$ & $\begin{array}{c}\text { Prosentase } \\
(\%)\end{array}$ & & \\
\hline$<70$ & 0 & 0 & 0 & 0 & 0 & 0 \\
\hline$>70$ & 12 & 18,8 & 52 & 81,3 & 64 & 100 \\
\hline Jumlah & 12 & 18,8 & 52 & 81,3 & 64 & 100 \\
\hline
\end{tabular}

Tabel 4 didapatkan bahwa mayoritas responden mendapatkan nilai praktikum edukator layanan darah $>70$ dan nilai UAS KIE dan Promosi Kesehatan yaitu nilai $>70$ yaitu sebanyak 52 responden $(81,3 \%)$ dan nilai praktikum edukator layanan darah <70 dan nilai UAS KIE dan Promosi Kesehatan yaitu nilai <70 yaitu sebanyak 12 responden $(18,8 \%)$. 
Tabel 5. Analisa Bivariat Nilai Praktikum Edukator Layanan Darah Terhadap Nilai UAS KIE dan Promosi Kesehatan menggunakan uji koefisien korelasi Spearman's rho

\begin{tabular}{|c|c|c|c|c|}
\hline \multicolumn{5}{|c|}{ Correlations } \\
\hline & & & $\begin{array}{l}\text { Nilai } \\
\text { Praktikum } \\
\text { Edukator } \\
\text { Layanan } \\
\text { Darah }\end{array}$ & $\begin{array}{l}\text { UAS KIE dan } \\
\text { Promosi } \\
\text { Kesehatan }\end{array}$ \\
\hline \multirow[t]{8}{*}{ Spearman's rho } & Nilai Praktikum & Correlation & 1.000 & $.693 * *$ \\
\hline & Edukator Layanan Darah & Coefficient & & \\
\hline & & Sig. (2-tailed) & . & .000 \\
\hline & & $\mathrm{N}$ & 64 & 64 \\
\hline & UAS KIE dan Promosi & Correlation & $.693 * *$ & 1.000 \\
\hline & Kesehatan & Coefficient & & \\
\hline & & Sig. (2-tailed) & .000 & . \\
\hline & & $\mathrm{N}$ & 64 & 64 \\
\hline
\end{tabular}

Tabel 5 didapatkan bahwa nilai output didapatkan koefisien korelasi Spearman's rho sebesar 0,693 yang berarti nilai mendekati 1, sehingga hubungan antara nilai praktikum edukator pelayanan darah dengan nilai UAS KIE dan Promosi Kesehatan adalah kuat. Nilai koefisien bertanda positif yang berarti terjadi hubungan posistif, yang artinya jika nilai praktikum edukator pelayanan darah tinggi maka nilai UAS KIE dan Promosi Kesehatan juga tinggi atau jika nilai praktikum edukator pelayanan darah rendah maka nilai UAS KIE dan Promosi Kesehatan juga rendah. Nilai signifikansi sebesar 0,000 $<0,05$ maka hipotesis nol di tolak, artinya ada hubungan yang berarti antara nilai praktikum edukator pelayanan darah dengan nilai UAS KIE dan Promosi Kesehatan.

Tabel 1 didapatkan bahwa jumlah responden sebanyak 64 dengan nilai minimum praktikum edukator layanan darah yaitu 70 dan nilai maximum UAS KIE dan Promosi Kesehatan yaitu 60, nilai maximun praktikum edukator layanan darah yaitu 88 dan nilai maximum UAS KIE dan Promosi Kesehatan adalah 86, nilai mean praktikum edukator layanan darah yaitu 81,05 dan nilai mean UAS KIE dan Promosi Kesehatan adalah 76,16, nilai standar deviasi (SD) praktikum edukator layanan darah yaitu 4,061 dan nilai standar deviasi (SD) UAS KIE dan Promosi Kesehatan adalah 7,340. Hal ini sesui dengan teori belajar adalah merupakan kegiatan alami manusia (Mujiman H, 2011).

Tabel 2 didapatkan bahwa seluruh responden mendapakan nilai praktikum edukator layanan darah yaitu nilai $>70$ yaitu sebanyak 64 responden (100\%). Hal ini sesuai dengan teori bahwa model pendidikan dengan pendekatan ketrampilan proses dapat memungkinkan mahasiswa untuk melaksanakan praktik sehingga mudah dipahami terhadap kosep-konsep baru. Proses pembelajaran ini harus merangsang perasaan ingin tahu, karena dapat mendorong melakukan langkahlangkah untuk mencari fakta (Mujiman H, 2011).

Tabel 3 didapatkan bahwa mayoritas responden mendapatkan nilai UAS KIE dan Promosi Kesehatan yaitu nilai $>70$ yaitu sebanyak 52 responden $(81,3 \%)$ dan nilai $<70$ sebanyak 12 responden $(18,8 \%)$. Hal ini sesuai dengan teori bahwa 
tes prestasi merupakan semacam estimasi mengenai posisi relatif atau jenjang urutan individu menurut tingkat kemampuan atau tingkat performansinya pada suatu tugas yang, kadang-kadang, tidak juga dapat dibatasi dengan jelas (Azwar S, 2011).

Tabel 4 didapatkan bahwa mayoritas responden mendapatkan nilai praktikum edukator layanan darah $>70$ dan nilai UAS KIE dan Promosi Kesehatan yaitu nilai $>70$ yaitu sebanyak 52 responden $(81,3 \%)$ dan nilai praktikum edukator layanan darah $<70$ dan nilai UAS KIE dan Promosi Kesehatan yaitu nilai <70 yaitu sebanyak 12 responden $(18,8 \%)$. H ini sesuai dengan teori bahwa nilai yang diperoleh dalam tes, hendaknya tidak dijadikan tujuan utama bagi mahasiswa dalam belajar, tetapi digunakan sebagai sarana peningkatan motivasi untuk belajar (Azwar S, 2011). Berdasarkan pengalaman, maka mahasiswa akan belajar lebih giat dan berusaha lebih keras apabila mereka mengetahui bahwa di akhir program yang sedang ditempuh akan diadakan tes untuk mngetahui nilai dan prestasi mereka (Azwar S, 2011).

Tabel 5 didapatkan bahwa nilai output didaatkan koefisien korelasi Spearman's rho sebesar 0,693 yang berarti nilai mendekati 1, sehingga hubungan antara nilai praktikum edukator pelayanan darah dengan nilai UAS KIE dan Promosi Kesehatan adalah kuat. Nilai koefisien bertanda positif yang berarti terjadi hubungan posistif, yang artinya jika nilai praktikum edukator pelayanan darah tinggi maka nilai UAS KIE dan Promosi Kesehatan juga tinggi atau jika nilai praktikum edukator pelayanan darah rendah maka nilai UAS KIE dan Promosi Kesehatan juga rendah. Nilai signifikansi sebesar 0,000<0,05 maka hipotesis nol di tolak, artinya ada hubungan yang berarti antara nilai praktikum edukator pelayanan darah dengan nilai UAS KIE dan Promosi Kesehatan. Penelitian ini sejalan penelitian Lieskusumastuti A dan Riawati D tahun 2018 yang menyatakan bahwa ada hubungan signifikan antara keaktifan praktikum dengan hasil evaluasi ujian ANC pada Mahasiswa Prodi DIII Kebidanan Mamba'ul 'Ulum Surakarta yaitu dengan nilai $p(0,000)<0,005$.

Menurut teori bahwa kematian ibu di Indonesia di dominasi oleh tiga penyebab utama yaitu perdarahan, hipertensi dalam kehamilan dan infeksi. Salah satu upaya untuk menurunkan AKI mellahirkan adalah melalui pemenuhan kebutuhan darah bagi ibu melahirkan dengan komplikasi perdarahan, sehingga membutuhkan pelayanan darah yang aman dan berkualitas, serta perlu didukung dengan ketersediaan darah sesuai kebutuhan (Infodatin, 2017). Hal tersebut juga didukung oleh Undang-undang No, 36 Tahun 2014 tentang tenaga kesehatan mengatur pendidikan vokasi paling rendah adalah Diploma III. Sebagai contoh pendidikan Diploma III Teknologi Bank Darah. Pendidikan ini di tuntut profesionalisme melalui peningkatan pengetahuan, ketrampilan dan sikap tenaga kesehatan di bidang pelayanan darah. Adapun profil lulusan Diploma III Teknologi Bank Darah harus mampu bertindak sebagai teknisi pelayanan darah, pelaksana pengujian mutu produk darah dan edukator layanan darah (Kemenkes RI, 2018). Berdasarkan hal tersebut maka ada perkembangan ilmu pengetahuan dan teknologi di bidang kedokteran khususnya teknologi pelayanan darah, pengelolaan komponen darah dan pemanfaatannya dalam pelayanan kesehatan harus memiliki landasan hukum konsekuensi asas negara berlandaskan hukum., 
oleh karena itu pelayanan darrah hanya dilakukan oleh Sumber Daya Masyarakat (SDM) yang memiliki kompetensi dan kewenangan dan hanya dilaksanakan pada farsilitas pelayanan kesehatan yang memenuhi persyaratan (Menkes RI, 2015). Salah satu contohnya yaitu sebagai edukator layanan darah. Kompetensi ini perlu diterapkan sejak menjadi mahasiswa DIII Teknologi Bank Darah, artinya mahasiswa harus mampu menjadi teknisi dalam memberikan komunikasi, informasi, edukasi di pelayanan darah. Kompetensi berupa mampu memberikan komunikasi, informasi, edukasi di pelayanan darah yang dimasukkan dalam mata kuliah KIE dan Promosi Kesehatan.

\section{SIMPULAN}

Nilai signifikansi sebesar $0,000<0,05$ maka hipotesis nol di tolak, artinya ada hubungan yang berarti antara nilai praktikum edukator pelayanan darah dengan nilai UAS KIE dan Promosi Kesehatan

\section{SARAN}

Bagi institusi Akademi Teknologi Bank Darah Surakarta dapat meningkatakan kegiatan pratikum baik di dalam kelas maupun luar kelas khususnya pratikum edukator layanan darah. Bagi mahasiswa supaya lebih aktif belajar dikelas maupun diluar untuk meningkatkan kemampuan dan ketrampilan khususnya sebagai edukator layanan darah. Bagi peneliti selanjutnya diharapakan meneliti beberapa faktor yang mempengaruhi keberhasilan pembelajaran yang berhubungan sebagai edukator layanan darah pada mata kuliah Komunikasi Edukasi Informasi dan Promosi Kesehatan.

\section{DAFTAR PUSTAKA}

Azwar S, 2011. Tes Prestasi Edisi II. Yogyakarta: Pustaka Pelajar.

Infodatin, 2017. Pelayanan Darah Di Indonesia. Jakarta: Pusat Data dan Informasi Kementerian Kesehatan Republik Indonesia. https://pusdatin.kemkes.go.id/resources/download/pusdatin/infodatin/Pelaya nan-Darah-di-Indonesia-2017.pdf. Diakses tanggal 02 Maret 2020, Jam: 08.00 WIB.

Kemenkes RI, 2018. Kurikulum Inti Pendidikan Diploma III Teknologi Bank Darah. Jakarta: Kekenkes RI BPPSDM PPSDMK.

Lieskusumastuti A dan Riawati D, 2018. Hubungan Keaktifan Praktikum dengan Hasil Evaluasi Ujian Antenatal Care pada Mahasiswa Prodi DIII Kebidanan STIKES Mamba'ul 'Ulum Surakarta. Journal of Health Research Avicenna Volume 1 Nomor 1 Bulan Maret 2018. Hal: 73-81. https://jurnal.stikesmus.ac.id/index.php/avicenna/article/view/198. Diakses tanggal 02 Maret 2020, Jam: 08.00 WIB.

Mudjiman, 2011. Belajar Mandiri Pembekalan dan Penerapan. Surakarta: UPT.Penerbit dan Percetakan UNS (UNS Press). 
Menkes, 2014. Undang-undang No, 36 Tahun 2014 Tentang Tenaga Kesehatan. http://gajiroum.kemkes.go.id/data/UU_NO_36_2014.pdf. Diakses tanggal 02 Maret 2020, Jam: 08.00 WIB.

Menkes RI, 2015. Peraturan Menteri Kesehatan Republik Indonesia No.91 Tahun 2015 Tentang Standart Pelayanan Tranfusi Darah. http://www.hukor.kemkes.go.id/uploads/produk_hukum/PMK_No._91_ttg _Standar_Transfusi_Pelayanan_Darah_.pdf. Diakses tanggal 02 Maret 2020, Jam: 08.00 WIB. 